\title{
Two different ischaemic heart entities with the same clinical presentation
}

Dwa różne przypadki choroby niedokrwiennej serca z takim samym obrazem klinicznym

\author{
Vladimir Zdravkovic', Rada Vucic', Zorica Lazic ${ }^{2}$, Violeta Iric-Cupic', Marina Jovic ${ }^{1}$, Goran Davidovic ${ }^{1}$, \\ Nemanja Zdravkovic ${ }^{2}$ \\ ${ }^{1}$ Cardiology Center, Clinic for Internal Medicine, Clinical Center Kragujevac, Kragujevac, Serbia \\ ${ }^{2}$ Center for Molecular Medicine, Faculty of Medicine, University of Kragujevac, Kragujevac, Serbia
}

Post Kardiol Interw 2011; 7, 3 (25): 265-269

DOI: 10.5114/pwki.2011.24747

\begin{abstract}
In this article we report two patients with different ischaemic heart entities who had sustained chest pain and showed numerous abnormal electrocardiograms (ECGs). To our knowledge, this is a very important report for the differential diagnosis of acute coronary syndrome and hypertrophic cardiomyopathy, which may give almost identical clinical presentation, ECGs and laboratory findings, making coronarography necessary for final diagnosis.
\end{abstract}

Key words: acute coronary syndrome, hypertrophic cardiomyopathy, electrocardiogram, coronarography

\section{Streszczenie}

W artykule przedstawiono dwóch pacjentów z różnymi przyczynami niedokrwienia serca, którzy mieli utrzymujący się ból w klatce piersiowej oraz liczne nieprawidłowe zapisy EKG. Według wiedzy autorów jest to bardzo ważne doniesienie dotyczące diagnostyki różnicowej ostrych zespołów wieńcowych i kardiomiopatii przerostowej, które mogą dać niemal identyczny obraz kliniczny, zapis EKG i wyniki badań laboratoryjnych, a w celu ustalenia ostatecznego rozpoznania konieczne jest wykonanie koronarografii.

Słowa kluczowe: ostry zespół wieńcowy, kardiomiopatia przerostowa, elektrokardiogram, koronarografia

\section{Introduction}

Chest pain is one of the most frequent symptoms in patients who present themselves at the Emergency Center. In patients with myocardial ischaemia, the intensity of chest pain varies while spreading to the left shoulder and arm to the back, neck, mandible, teeth, rarely to the right arm and abdomen. When the patient suffers from stable angina pectoris, chest pain is usually provoked by an effort, a large meal, cold or emotional stress. However, in unstable angina, chest pain is often unrelated to the intensity of myocardial workload. Although primarily caused by stenosis of the coronary arteries, myocardial ischaemia can result from disproportionally increased myocardial demand for oxygen with coronary arteries of a normal diameter, e.g. in hypertrophic cardiomyopathy. Sometimes it is extremely difficult to differentiate between exact causes of myocardial ischaemia using only the patient's history, physical signs, electrocardiograms (ECGs) and laboratory findings (serum levels of troponin I or T and creatinine phosphokinase isoenzyme MB) [1].

In this article we present two cases of myocardial ischaemia with almost identical presentation, ECGs and laboratory findings, yet with different causes: acute coronary syndrome and hypertrophic cardiomyopathy.

\section{Case reports}

\section{Case 1}

A 51-year-old woman was admitted to the Coronary Unit (CU) due to sustained chest pain that started a few hours before. The ECG tracings demonstrated possible 
acute coronary syndrome without ST segment elevation (NSTE-ACS). The patient had a history of two decades of smoking, hypertension and coronary disease in her family.

Physical examination did not reveal abnormalities of the heart and lung functions; arterial blood pressure was $175 / 105 \mathrm{mmHg}$ and heart frequency 90 beats per minute (bpm). The ECG revealed sinus rhythm (90 bpm), semihorizontal position of the electrical axis of the heart, inverted T-waves in V1, V2, V3 and biphasic T-waves in V4 derivation (fig. $1 \mathrm{~A}$ ). During the $2^{\text {nd }}$ and the $3^{\text {rd }}$ day of hospitalization T-waves in V1, V2, V3 and V4 became more negative and $\mathrm{T}$-waves in $\mathrm{V} V \mathrm{~L}$ derivation were presented as horizontal (fig. 1 B).

Serum level of troponin I was $0.15 \mathrm{ng} / \mathrm{ml}$, and the levels of other myocardium-specific enzymes were within normal ranges; only the level of cholesterol was increased (total cholesterol $6.3 \mathrm{mmol} / \mathrm{l}, \mathrm{LDL} 4.2 \mathrm{mmol} / \mathrm{l})$. Ultrasonography of the heart was mostly normal, with slightly impaired contractions of anterior and lateral walls of the left ventricle (data not shown).

\section{Case 2}

A 54-year-old woman who was experiencing chest pain for several hours was also admitted to the CU with ECG findings suggesting NSTE-ACS. The patient had a history revealing hypertension for more than a decade and coronary disease in the family.

Besides slightly accented second tone over the aortic valve, other abnormalities were not found after the physical examination of the heart and lungs. Arterial blood pressure was $130 / 85 \mathrm{mmHg}$ and pulse $60 \mathrm{bpm}$. The ECG at admission showed left anterior hemiblock, inverted T-waves in D1, D2, aVL, aVF and V2-V6, decreased R waves in V2$\mathrm{V} 5$ and a prolonged QT interval (QTc was over $470 \mathrm{~ms}$ ) (fig. $1 \mathrm{C}$ ). On the $2^{\text {nd }}$ day in hospital, the T-wave inversion became more pronounced (fig. $1 \mathrm{D}$ ) and an episode of paroxysmal atrial fibrillation occurred (fig. $1 \mathrm{E}$ ).

Laboratory tests showed increased serum lipids (total cholesterol $6.4 \mathrm{mmol} / \mathrm{l}, \mathrm{LDL} 3.7 \mathrm{mmol} / \mathrm{l})$, the first value of troponin $10.18 \mathrm{ng} / \mathrm{ml}$ and normal values of other myocardium-specific enzymes. Ultrasonography of the heart showed normal kinetics of the left ventricle with concentric
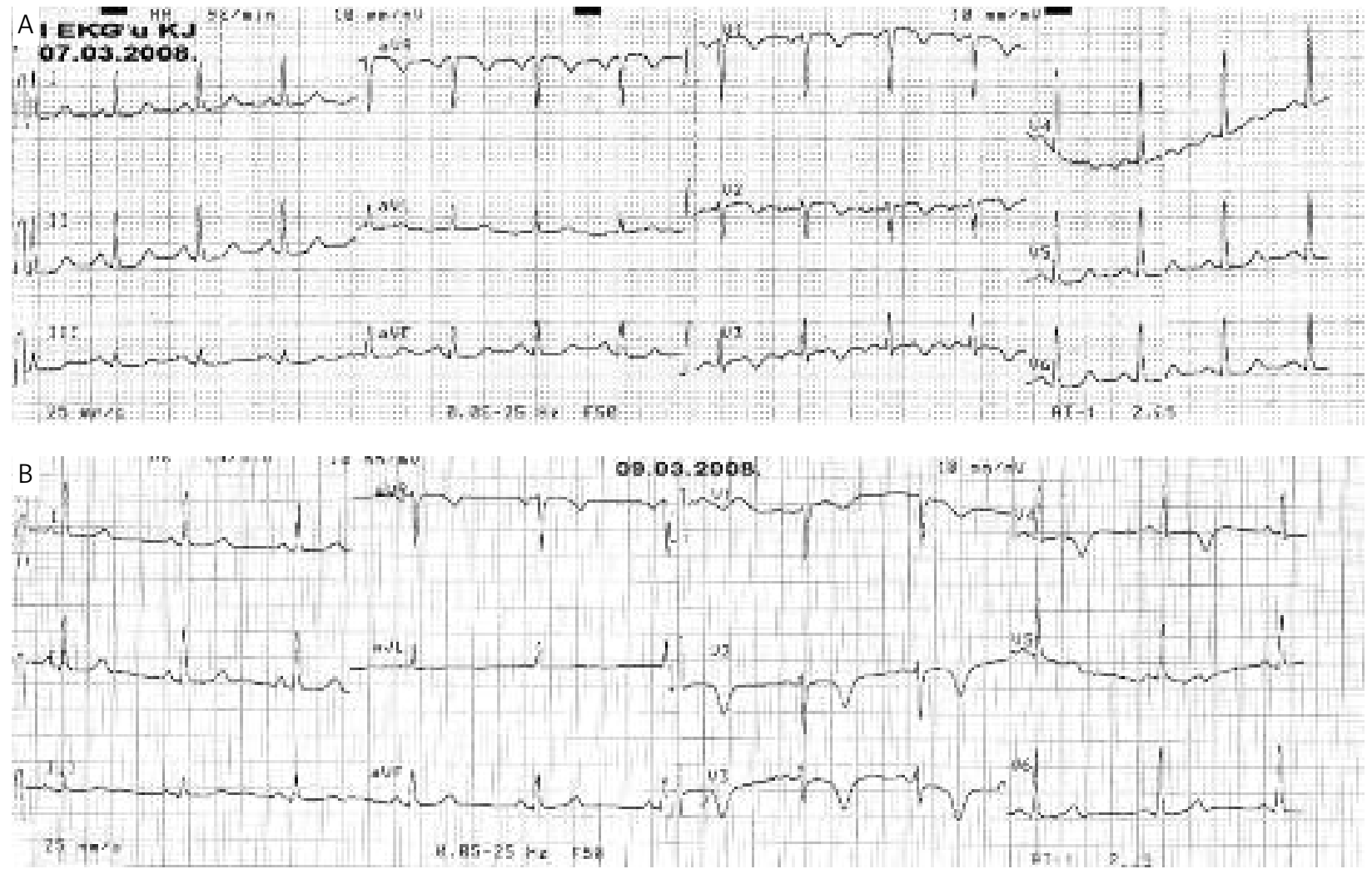

Fig. 1. Electrocardiograms on admission showing inverted T-waves in both cases (A and C). Over time, T-wave inversion became more pronounced, with dynamic changes in both patients ( $B$ and $D$ ). Paroxysmal atrial fibrillation was registered only in the patient with hypertrophic cardiomyopathy (E)

Ryc. 1. Zapis EKG przy przyjęciu: w obu przypadkach widoczne są odwrócone załamki T (A i C). W późniejszych zapisach EKG odwrócone załamki T są głębsze, z dynamicznymi zmianami u obu pacjentów (B i D). Jedynie u pacjenta z kardiomiopatią przerostową zarejestrowano napad migotania przedsionków (E) 

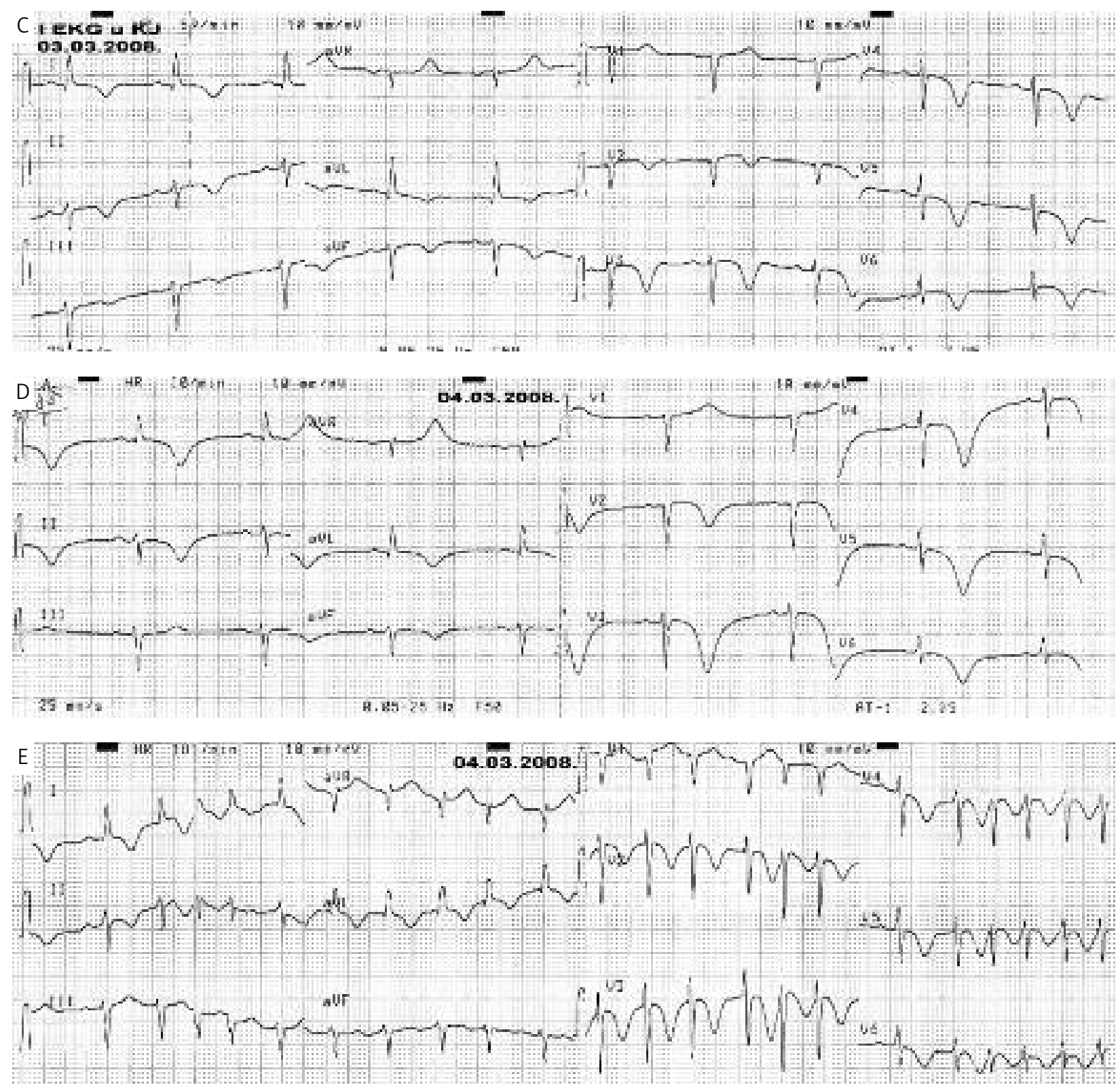

Fig. 1. cont.

Ryc. 1.cd.

wall thickening (e.g. IVSd - 14 mm, LVPWd - 12 mm, apexd - $12 \mathrm{~mm}$; data not shown).

Since the underlying pathology was not clear in both cases, they were treated as acute coronary syndrome and percutaneous endovascular coronarography was performed. The coronarogram of the second patient was normal (fig. 2 A, B), while in the first patient the median segment of the anterior descending branch of the left coronary artery showed narrowing of $90 \%$ (fig. 2 C); the narrowing was treated by placing two stents during the same procedure (fig. $2 \mathrm{D}$ ). After these procedures, both patients recovered uneventfully and were discharged from hospital after 10 days.

\section{Discussion}

Electrocardiogram plays a critical role in the diagnostics of myocardial ischaemia and its causes. If there is an ischaemic zone within the myocardium, it causes the emergence of negative, symmetrical and peaked T-waves, known as "ischaemic" or "coronary" waves [2]. In our two cases, the ECG diagnosis showed numerous almost identical abnormal findings in acute coronary syndrome and hypertrophic cardiomyopathy (HCM). The ECGs in both patients showed negative T-waves (fig. $1 \mathrm{~A}, \mathrm{C}$ ), and during this period they became more negative with dynamic changes (fig. 1 B, D). The amplitude and width of negative 
T-waves vary, but they are most pronounced in ECG derivations directed towards the ischaemic zone [3]. "Ischaemic" T waves in V1, V2 and V3 derivations appeared in the ECG of the first patient, indicating the damage of the left ventricle anteroseptal walls. The ECG of the second patient was presented with negative T-waves in D1, D2, $\mathrm{aVF}, \mathrm{VVL}$ and $\mathrm{V} 2$ to $\mathrm{V} 5$ derivations, indicating a more severe ischaemic zone (possible damage of inferior, anteroseptal and lateral walls). Patients with HCM can experience myocardial ischaemia or even myocardial infarction without narrowing of large epicardial coronary arteries; ischaemia is caused by the decrease in blood flow through small
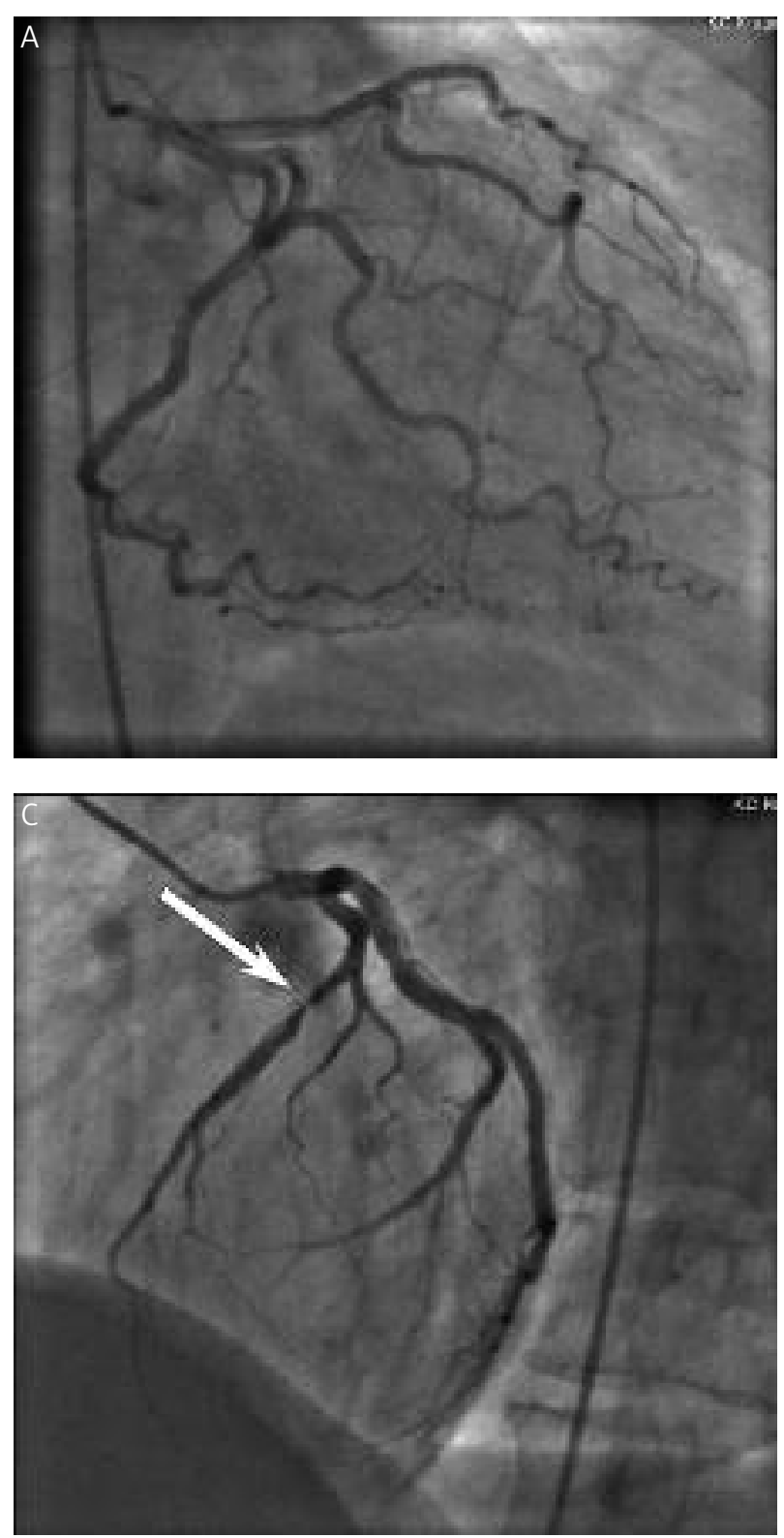

intramural arteries which are partly obliterated [4]. Troponin I serum level is always increased in NSTE-ACS patients [5]. Also, the elevation of this cardiospecific enzyme occurred in patients with left ventricular hypertrophy [6].

Both patients showed an increased troponin I serum level $(0.15 \mathrm{ng} / \mathrm{ml}$ was the value in the first patient and $0.18 \mathrm{ng} / \mathrm{ml}$ in the second one), while the levels of other myocardium-specific enzymes were within normal ranges in both patients. The majority of patients with HCM have abnormal ECG: left deviation of the heart axis is present in $30 \%$ of these patients, and other ECG signs of left ventricular hypertrophy can be noted in $17-18 \%$ of the
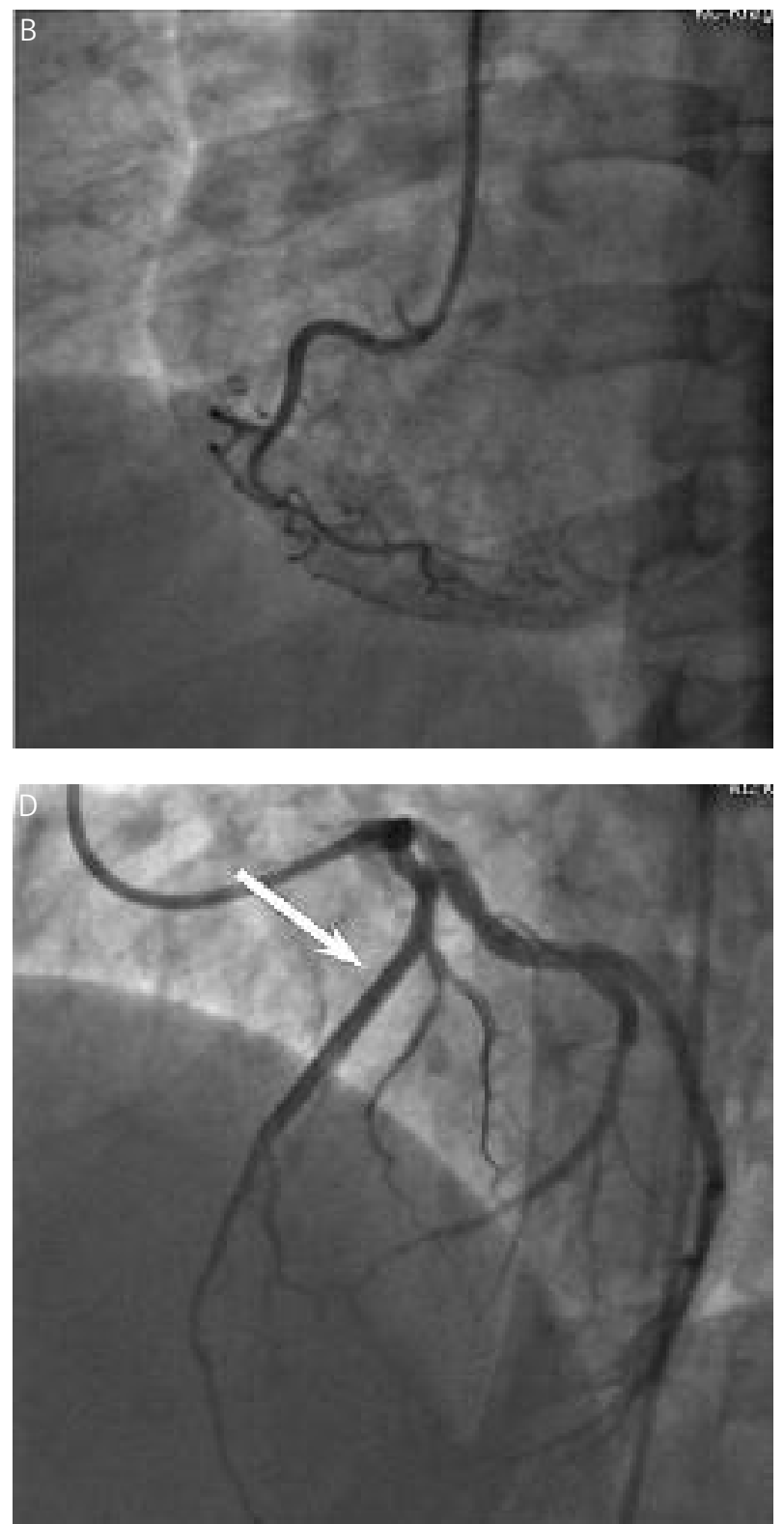

Fig. 2. Case 2: normal coronarogram left (A) and right (B) coronary arteries. Case 1: coronarogram before (C) and after (D) stent implantation

Ryc. 2. Przypadek nr 2: prawidłowa koronarografia lewej (A) i prawej tętnicy wieńcowej (B). Przypadek nr 1: koronarografia przed wszczepieniem (C) i po wszczepieniu stentu (D) 
patients; further, QT intervals can be longer in hypertrophic patients without any differences between hypertensive LVH and HCM [7]. There were no ECG signs of left ventricle hypertrophy in the first or in the second patient (SokolowLyone score was under $35 \mathrm{~mm}$, Cornell voltage criteria were under $22 \mathrm{~mm}$ ), but prolonged QTc occurred in the second one. Acute coronary syndrome can be presented with paroxysmal atrial fibrillation (AF) [5]; also the same arrhythmia was registered using Holter ECG in $30 \%$ of the patients with HCM [8]. Atrial fibrillation episodes were present only in the patient with hypertrophic cardiomyopathy (fig. $1 \mathrm{E}$ ), which can pose a significant problem in ECG differential diagnosis of these two different ischaemic heart entities.

In our two cases, apart from the signs of ischaemia in ECG, serum levels of troponin I were above the normal range in both patients, suggesting the existence of ischaemia. However, many other conditions (such as pulmonary embolism, chronic renal insufficiency, cerebral infarction, etc.) also cause elevation of troponin I serum levels, making differential diagnosis more difficult [9]. Even ultrasonography of the heart does not add much to the differentiation of the causes of myocardial ischaemia [10]: in our two cases only a subtle loss of contractility in the first and the thickening of the walls in the second patient were noted, leaving us without a definite clue as to the causes of the patient's condition.

It was only coronarography which revealed the true causes of ischaemia in our two patients, and made a rapid therapeutic intervention possible (placement of stents) in one of these patients whose ischaemia was caused by narrowing of large epicardial segments of the coronary arteries. Although invasive and accompanied by a significant risk of serious complications, coronarography is often the only method which may help in establishing causal diagnosis of myocardial ischaemia and in administering appropriate treatment. Therefore, if noninvasive diagnostic methods (recording the patient's history, performing physical examination, ECG, ultrasonography and measuring serum levels of cardiac enzymes) do not provide sufficient probability of final diagnosis, cardiologists should not hesitate to perform coronarography in order to reach causal diagnosis and administer appropriate treatment in a timely manner.

\section{Acknowledgments}

We would like to thank Marija Zdravkovic for language revision of the manuscript.

\section{Conflict of interest}

The authors declare that there is no duality of interest associated with this manuscript.

\section{References}

1. Karnath B, Holden MD, Hussain N. Chest pain: differentiating cardiac from noncardiac causes. Hospital Physician 2004; 40: 24-38.

2. Picanoa E, Pálinkás A, Amyot R. Diagnosis of myocardial ischemia in hypertensive patients. J Hypertens 2001; 19: 1177-1183.

3. Severi S, Grandi E, Pes C, et al. Calcium and potassium changes during haemodialysis alter ventricular repolarization duration: in vivo and in silico analysis. Nephrol Dial Transplant 2008; 23: 1378-1386.

4. Roberts R, Sigwart U. New concepts in hypertrophic cardiomyopathies, part I. Circulation 2001; 104: 2113-2116.

5. Lau DH, Huynh LT, Chew DP, et al. Prognostic impact of types of atrial fibrillation in acute coronary syndromes. Am J Cardiol 2009; 104: 1317-1323.

6. Hamwi SM, Sharma AK, Weissman NJ, et al. Troponin-l elevation in patients with increased left ventricular mass. Am J Cardiol 2003; 92: 88-90.

7. Lazzeri C, Barletta G, Badia T, et al. Multiparametric electrocardiographic evaluation of left ventricular hypertrophy in idiopathic and hypertensive cardiomyopathy. Ital Heart J 2005; 6: 304-310.

8. Dumont CA, Monserrat L, Soler R, et al. Interpretation of electrocardiographic abnormalities in hypertrophic cardiomyopathy with cardiac magnetic resonance. Eur Heart J 2006; 27: 1725-1731.

9. Kucher N, Goldhaber SZ. Cardiac biomarkers for risk stratification of patients with acute pulmonary embolism. Circulation 2003; 108: 2191-2194.

10. Penas-Lado M, Barriales-Villa R, Arias J. Apical hypertrophic cardiomyopathy, intraventricular pressure gradients and ST segment elevation. Int J Cardiol 2002; 82: 179-180. 